\title{
Lumen
}

Selected Proceedings from the Canadian Society for Eighteenth-Century Studies

\section{Sir Charles Grandison and the Sexual Politics of Toleration}

\section{Alison Conway}

Volume 30, 2011

URI : https://id.erudit.org/iderudit/1007712ar

DOI : https://doi.org/10.7202/1007712ar

Aller au sommaire du numéro

Éditeur(s)

Canadian Society for Eighteenth-Century Studies / Société canadienne d'étude du dix-huitième siècle

ISSN

1209-3696 (imprimé)

1927-8284 (numérique)

Découvrir la revue

Citer cet article

Conway, A. (2011). Sir Charles Grandison and the Sexual Politics of Toleration. Lumen, 30, 1-19. https://doi.org/10.7202/1007712ar

Copyright (c) Canadian Society for Eighteenth-Century Studies / Sociéte canadienne d'étude du dix-huitième siècle, 2011
Ce document est protégé par la loi sur le droit d'auteur. L’utilisation des services d'Érudit (y compris la reproduction) est assujettie à sa politique d'utilisation que vous pouvez consulter en ligne.

https://apropos.erudit.org/fr/usagers/politique-dutilisation/ 


\section{Sir Charles Grandison and the Sexual Politics of Toleration}

Two concerns preoccupied eighteenth-century readers of Sir Charles Grandison: that the hero's ability to love two women simultaneously compromised the emotional, if not the moral, integrity of his character; and that the novel's willingness to entertain the idea of an interfaith marriage set a dangerous precedent. On the first subject, Lady Bradshaigh announced, "Say what you will, it is impossible for a Man to be equally in Love with two Angels at the same time. ${ }^{11}$ On the second, the Reverend Cox Macro bemoaned the novel's contribution to a growing tide of mixed marriages: "if you had pleased to have made use of that Handle to expose the Iniquitys of such a Practice ... some few of those Reasons which you would have then brought might have done more Service towards putting a stop to so wicked a practice, than the best Discourses upon it could have done. ${ }^{\prime 2}$ Richardson, as usual, had ample defences ready but conceded that "the Delicacy of the Situations" his "double love" involved might strain the sympathy of his readers. ${ }^{3}$ Regarding the novel's flirtation with a Protestant-Catholic union, he emphasized that the hero's willingness to make religious accommodations was borne of compulsion rather than desire. In his "Concluding Note" to the novel, he allowed to stand unchallenged his readers' assessment that this willingness to bend constituted "a blot in the character" of Sir Charles. ${ }^{4}$

This essay suggests that these two concerns - the integrity of the heart and the limits of religious toleration - prove intimately related in

1 Quoted by Richardson in a letter to Lady Bradshaigh, 8 Dec. 1753. Selected Letters of Samuel Richardson, ed. John Carroll (Oxford: Clarendon Press, 1964), p. 252.

2 Quoted in T. C. Duncan Eaves and Ben D. Kimpel, Samuel Richardson: A Biography (Oxford: Clarendon Press, 1971), p. 411.

3 Quoted in Eaves and Kimpel, Samuel Richardson, p. 407.

4 The History of Sir Charles Grandison, 3 vols., ed. Jocelyn Harris (London: Oxford University Press, 1972), vol. 3, p. 464. Future references will be cited parenthetically by volume and page number. 


\section{Alison Conway}

Grandison and that the imperatives governing love and tolerance jostle uncomfortably in the novel. Harriet Byron's "whole heart," I claim, sustains the affective logic of the sentimental novel, whose goal is a marriage of equal minds. In contrast to Harriet's emotional zealotry, reserve defines Sir Charles's character. This trait manifests a public commitment to duty, discretion, and careful judgment, as well as an attitude of religious tolerance. Privately, it shields a divided heart from scrutiny until such a time as it can find a home in marriage. But the competing interests of whole and divided hearts, of zealotry and detachment, do not so simply resolve their differences across the diachronic time of the narrative. Rather, each brings into sharp focus the terms governing the other. ${ }^{5}$ Harriet's pursuit of a union of equal minds is subordinated, finally, to the "natural" imperatives, both affective and biological, that govern family life. In this regard the novel exposes Richardson's desire, conscious or unconscious, to contain the evolution of feminist ideas (to which Clarissa contributed no small part) in mid-century England. But if Harriet never thinks to look outward, Sir Charles rarely looks inward. His ethics of tolerance, defined by its interest in good governance, cannot extend beyond outward forms to the heart of religious alterity without risking a radical re-thinking of identity and difference - including sexual difference. The novel can only, finally, entertain limited ideas of equality, both sexual and religious, but in doing so it starkly reveals the fault lines running through emergent liberal discourses. ${ }^{6}$

5 Wendy Brown's analysis of nineteenth-century conceptualizations of the "Woman question" and the "Jewish question" informs my reading of Grandison. Brown observes: "Both exclusions [of women and of Jews] were justified by an imagined difference from the figure of universal man at the heart of the emerging European constitutional political orders. ... Why did one emancipation movement, then, remain within the rubric of tolerance and conditional inclusion while the other took shape as a project of political equality?" Regulating Aversion: Tolerance in the Age of Identity and Empire (Princeton: Princeton University Press, 2006), p. 49. In 1754, we are not yet in the world Brown describes, but her question draws our attention to the places where the interests of women and Catholics intersect and diverge in the novel.

6 My reading qualifies Kathryn Temple's reading of Grandison, which claims that the novel's interest in toleration merely cloaks its imperial and colonizing impulses: "[I]t is 'tolerance' that allows Englishness to dominate internationally." "Printing Like a Post-Colonialist: The Irish Piracy of Sir Charles Grandison." Novel: A Forum on Fiction 33.2 (2000): 157-74. While helpful in drawing our attention to Richardson's engagement with colonial politics in the wake of the publication of the pirated Irish edition of Grandison 1753, Temple's reading of the novel risks flattening the terrain of complex mid-century arguments about religious toleration. It also underestimates the significance of the controversy generated by Grandison's 


\section{Harriet Byron, Zealot}

Harriet responds to her accidental introduction to the Grandison family by committing herself to its interests and by falling in love with the man of the house. We discover that Sir Charles compels love in all who meet him, but Harriet proves unique in the conviction she brings to bear on her attachment. That is, while we know that several other young women will be disappointed in their expectations - after all, not everyone can marry this paragon - we don't hear any accounts that would suggest they are inclined to adopt Harriet's idealist stance. As a young girl, Harriet was identified as "an enthusiast" (1.178) and she tenaciously defends her right to remain true to her attachment to the active exclusion of those who might want to compete for her affection: "Since I have seen and known Sir Charles Grandison, I have not only (as before) an indifference, but a dislike, to all other men" (1.218). She writes to Charlotte, "He was my first Love; and I will never have any other" (2.542). The zealotry of Harriet's love marks her as an independent thinker whose belief in the freedom of conscience, here shifted into an affective register, grants her the liberty to pursue truth as she defines it. ${ }^{7}$ Zealotry, that is, guarantees the disinterestedness of Harriet's claims, for it sets her affect apart from pragmatic and material

tolerance, both within the novel itself and among its readers. Lucy Selby, late in the narrative, imagines the consequences should Sir Charles and Clementina have married: "how was this noble-minded man entangled by delicacies of situation, by friendship, by compassion, that he should ever have been likely to be engaged in a family of Roman Catholics, and lived half of his days out of his beloved Country! And the other half to have set, as to the world's eye, such an Example in it!" (3. 264). The author of Critical Remarks on Sir Charles Grandison, Clarissa, and Pamela (1754) notes, "I am afraid there could have been no compleat happiness in the matrimonial union of the English Gentleman and the Italian Lady ... [T] he difference in religious sentiments would have been a great allay of that illustrious couple" (6). Clearly Sir Charles's willingness to engage these subjects contravenes communal standards. On the subject of Grandison's politics and toleration, see also: Wolfgang Franke, "Richardson's Grandison as a Novel for Debate." Functions of Literature: Essays Presented to Erwinn Wolff on His Sixtieth Birthday, ed. Ulrich Broich, Theo Stemmler, and Gerd Stratmann. Tübingen: Niemeyer, 1984: 173-93) and Teri Doerksen, "Sir Charles Grandison: The Anglican Family and the Admirable Roman Catholic," Eighteenth-Century Fiction 15.3-4 (2003): 539-58.

7 My reading of Harriet's love as anchoring her identity draws on Katherine Binhammer's claim that "love, not desire, is the 'master key' for female subjectivity" in the eighteenth century." The Seduction Narrative in Britain, 1747-1800 (Cambridge: Cambridge Univ. Press, 2009), p. 9. 
concerns. The excessiveness of her pronouncements guarantees the quality of their content, for it manifests the presence of a feeling heart.

The language of the "whole heart," to which the novel returns over and over again, shores up our sense that Harriet's intentions are always complete and uncompromised. Early in the narrative, Harriet asserts that she will marry only on the condition that her "whole undivided heart" fix itself on a suitable object (1.15). Interrogated by Sir Hargrave about her willingness to marry, Harriet replies, "Perhaps I may, if I meet with a man to whom I can give my whole heart" (1.112). Having met and fallen in love with Sir Charles, she admits, "[he] has possession of my whole heart" (1.422). Harriet claims the value of the whole heart as a universal principle of affective relations; the whole heart must meet its identical, and mutually engaged, mate in order for marriage to meet the standard of integrity she maintains. Harriet takes her affair public, defending her love of Sir Charles as a subject larger than a mere "hopeless passion" (1.278). To Sir Rowland Meredith she writes: "If you knew him, you would love him yourself, and own him for a son ... Enquire about him. His character will rise upon you from every mouth ... [M] $\mathrm{y}$ esteem for this noblest of men is of such a nature, that I cannot give my hand to any other" (2.404). Defending her passion to Lady G., Harriet stresses, again, that her love meets a public standard and therefore merits her commitment: "Love merely personal ... may, I believe, and perhaps generally ought to, be subdued. But Love that is founded on a merit that every-body acknowledges - I don't know what to say to the vincibility of such a Love" (3.31).

The moral integrity of Harriet's attachment allows her love to take on the status of an ethical imperative. In her willingness to defend her right to love on her own terms, Harriet anticipates the heroines of later eighteenth-century narratives, including those feminists who populate the Jacobin novels of the 1790s. To the proposal of marriage to the Earl of D., Harriet replies, "I would not, for twelve times my Lord's 12,000l. a year, give my hand to him, or to any man, while another had a place in my heart; however unlikely it is, that I may be called by the name of the man I prefer" (1.309). As a quality of character linked to a moral standard, Harriet's commitment becomes part of who she is, not just in the moment of courtship, but forever. When invited to move forward in the wake of news regarding Sir Charles's Italian connection, she writes, "My heart is already a wedded heart" (2.289). Confronted with the possibility of Sir Charles' alliance with Clementina, Harriet resigns the world of marriage rather than break the tie her love has forged: "His I cannot expect to be: I must then of necessity be a single woman as long as I live" (1.390). In this register, Harriet's love takes on a timeless and 
abstract quality, even as it generates our desire for the marriage plot that will allow for its realization as a lived practice.

Harriet laments, in the wake of learning of Sir Charles's Italian affair, "[N]ow my ambition has overthrown me: Aiming, wishing to be everything, I am nothing. If I am asked about him, or his sisters, I shall seek to evade the subject; and yet, what other subject can I talk of ... And what indeed but Him and Them, since I have known this family, have I wished to see, and to know?" (2.181). Harriet's language of ambition adds a new dimension to her affective zeal. The political content of Harriet's passion appears explicitly when she links her affective claims to debates concerning women's place in society:

[Love] which is founded on interior worth; that blazes out when charity, beneficence, piety, fortitude, are signally exerted by the object beloved; how can such a Love as that be restrained, damped, suppress'd? How can it, without damping every spark of generous goodness, in what my partial grandmamma calls a fellow-heart, admiring and longing to promote and share in such a glorious philanthropy?

Philanthropy! - Yes, my uncle: Why should women, in compliance with the petulance of narrow-minded men, forbear to use words that some seem to think above them, when no other single word will equally express their sense. It will be said, They need not write. Well then, don't let them read: And carry it a little further, and they may be forbidden to speak. And every lordly man will then be a Grand Signor, and have his mute attendant. ${ }^{8}$

Love that has its roots in a conviction of the love object's public worthiness seeks to unite itself to that object in order to expand the scope of activity for "philanthropy"; the union of two-ethically committed hearts, that is, obviates the division of labor that designates only men as philanthropic agents. Harriet does not focus merely on the practical side of things (i.e. that two hands are better than one), but elevates her claim to a more abstract level, whereby women's claim to the public term "philanthropy" marks the necessity of their inclusion in a community of sexless minds united in a common effort of bettering the world. Against this vision of sociability she pits the Ottoman master and his "mute attendant," the arbitrary tyrant who imposes silence on his subjects. 
Harriet's pronouncements set her at odds with her community and its commitment to the regulation of marriage, a subject on which the novel dwells at length. ${ }^{9}$ Mrs. Shirley provides a long disquisition against romantic love, using her own case as an example of the success of a marriage founded on esteem rather than desire. The sage Mrs. Eggleton, whose wisdom Mrs. Shirley recounts, warns her young protégé against the worship of false idols: "You look upon Love as a blind irresistable Deity, whose darts fly at random, and admit neither defence nor cure ... The passions are intended for our servants, not our masters, and we have, within us, a power of controuling them, which it is our duty to exert" (3.399). Romances are singled out as a particularly dangerous contributor to women's delusional thinking, against which common sense and prudence must wage battle. ${ }^{10}$ But Harriet's ability to unite reason and passion challenges the ethics of prudence, exposing their tendency to mask the emotional bankruptcy of women and men who allow themselves to be traded in the marketplaces of capital and pedigree. As Wendy Jones notes of the Shirley/Eggleton paradigm, "Although interest is supposedly subordinated to inclination in the companionate marriage, since one should not marry unless a 'preference' exists, this preference, based as it is on balanced and deliberate judgment, is in danger of overvaluing the material or social advantages of marriage." ${ }^{\prime 11}$ The novel cannot contain the radical import of Harriet's claims simply by asserting the superiority of her love object - that is, by marking her quest as singular. In this very social novel, she strikes an exemplary note.

The novel effectively re-routes Harriet's idealism by harnessing it to a domestic program. ${ }^{12}$ Harriet claims that "Love is a narrower of the

9 Wendy Jones provides an insightful analysis of the novel's representation of "companionate" and "sentimental" love in "The Dialectics of Love in Sir Charles Grandison," Eighteenth-Century Fiction 8.1 (1995): 15-34. I disagree with her contention that "despite the superiority of sentimental love, it cannot be openly advocated" (31). In the same way that Clarissa never resolves its central paradox - parents should be obeyed, but Clarissa could never be married to Solmes - so too Grandison sustains a contradiction: Harriet's conduct is faultless, but no other character in the novel may imitate it.

10 Albert J. Rivero adroitly untangles the romance/realism knot in "Representing Clementina: 'Unnatural' Romance and the Ending of Sir Charles Grandison." New Essays on Samuel Richardson, ed. Rivero (New York: St. Martin's Press, 1996), pp. 209-25.

11 Jones, "The Dialectic of Love in Sir Charles Grandison," 26-7.

12 Amanda Vickery and others have effectively challenged Nancy Armstrong's thesis 
heart" (1.131) and asserts, after her marriage, that "Sir Charles and his relations and mine, are the world to me" (3.282). The expansiveness of her vision, as it turns out, reaches only the horizon of the family unit, protectively closed off from both a larger English social arena and the culture of Continental Europe. Harriet's discovery of a family "that ha[s] no need to look out of itself for entertainment" leads to a larger conclusion - that there is nothing more to the world than this family (2.407). We are not surprised when a jealous Harriet writes, "I wish this word foreign were blotted out of my vocabulary; out of my memory, rather" (2. 110). In the same vein, Harriet traces Clementina's emotional downfall to her parents' cosmopolitan tendencies: "Teach her English! - Very discreet in the father and mother, surely" (2.156). The whole heart, in turns out, cannot encompass the whole world, but only those individuals who seem familiar.

When Harriet thinks of tolerance and difference, she thinks of mediocre marriages - in particular, marriages of convenience, in which "partners deal with tolerable honesty with each other ... Tolerable, I repeat, since, it seems we are to expect that both parties will turn the best side of the old garment outward" (2.334). The idea of the tolerable defines an emotional compromise that we know Harriet would not apply to her own case, and it reminds us of her earlier pronouncement: "I am in earnest, that I could never be satisfied with a divided heart" (2.492). Harriet is not required to think about tolerance in a larger context, in part because the one question that requires a broader frame of reference - that is, the question of religious difference - is one she actively avoids. As a religious subject, Harriet demonstrates both piety and restraint. Early in the narrative, Harriet tells Sir Hargrave that the subject of immortality is "a very material consideration with me, tho' I am not fond of talking upon it, except on proper occasions, and to proper persons" (1.96). At the end of the novel, describing the gatherings of the Catholic and Protestant families at Grandison Hall, Harriet notes, approvingly, that "Nothing of religious subjects is ever mentioned among us, but in those points in which all good Christians agree" (3.410). We are reminded, here, of the limits of Locke's conceptualizations of religious toleration (to which I return below), directed toward the management of intra-Protestant differences in the wake of

that domestic ideology increasingly restricted women to the home in eighteenthcentury Britain. But Grandison sets in stark opposition those women who wander and those who don't. The family and the family seat take on significance in the novel's larger political landscape, which space precludes me from drawing here. 
the seventeenth-century civil war rather than a more fundamental recognition of alterity. The passion of Harriet's affective conviction never threatens to compromise the quietness of her religious life. Indeed, the one guarantees the other.

The fact that Harriet's philanthropic republic, so boldly claimed for women and men alike early in the narrative, ends up restricting itself to conversations in the cedar parlour proves no accident. Richardson insists, finally, that the sexed body, most profoundly expressed in maternity, necessarily limits women's capacity to exercise their sexless intellect. Sir Charles opines, "Supposing, my Charlotte, that all human souls are, in themselves, equal; yet the very design of the different machines in which they are inclosed, is to super-induce a temporary difference on their original equality; a difference adapted to the different purposes for which they are designed by Providence in the present transitory state" (3.250). Not only does Sir Charles's assertion of the significance of bodily difference qualify Harriet's earlier assertions, it effectively alters their parameters. Rather than imagining the union of unsexed "whole hearts" as its end point, Grandison waits on pregnancy to bind men and women in a more compelling fashion..$^{13}$ This trajectory is rather crudely drawn in the story of Charlotte Grandison's marriage, but its more subtle articulation appears again in the representation of Harriet's. Only when her pregnancy is at risk and Harriet is nursed back to health by her husband does she feel secure in his love: "So amiably has he appeared in this new light ... that tho' I wanted not proofs before of his affection for me, I cannot account my indisposition an unhappiness; especially as it has gone off without the consequences, of which you were so very apprehensive" (421). Sir Charles, who tends to view women as children - "He treats us ... as perverse humoursome babies," Harriet observes - can more perfectly recognize his wife when she carries his child (2.272). Unlike Clarissa, which characterizes the Harlowes' and Lovelace's obsession with the idea of pregnancy as the sign of misogyny and familial oppression in its closing pages, Grandison remains confident that women step into full personhood when they become mothers. ${ }^{14}$ Affective zealotry, then, emancipates the mind

13 As Wendy Brown notes, "a presumption of difference, organized by a heterosexual division of labor, and underpinned by a heterosexual family ... underscore[s] the difference between formal and substantive equality." Regulating Aversion, p. 74.

14 Ruth Perry traces the evolution of Richardson's increasingly conservative views of sexual difference and maternity, focusing her attention on his representation of breast-feeding: "by the time of Sir Charles Grandison, a woman's wifely obedience 
so that it can better find its way home to the body. As it turns out, only in the after-life only will Harriet's unsexed principle of Philanthropy will find its realization: "women will certainly be on a foot with men, as to intellectuals, in Heaven," Sir Charles concedes (3.250).

\section{Sir Charles Grandison, Cosmopolitan}

Richardson wrote his final novel at a moment when the idea of religious difference was at the forefront of the English mind. The Stuart invasion of 1745 revived fears of Catholic encroachment; Methodism was on the rise; and efforts to pass a Jewish Naturalization Act of 1753 re-animated centuries-old anti-Semitism. ${ }^{15}$ Grandison's positive treatment of its Catholic characters strikes a conciliatory note at a time of heightened tension, as does its willingness to characterize Methodism as an effective cure for someone like Mrs. O'Hara and its refusal to link Solomon Merceda's faults to his Jewish faith. Sir Charles's cosmopolitan life abroad establishes a conduit for reflections on toleration. Early in the third volume, Mr. Deane remarks, "Seas are nothing to him ... [Sir Charles] considers all nations joined on the same continent; and [Dr. Bartlett] doubted not but if he had a call, he would undertake a journey to Constantinople or Pekin, with as little difficulty as some others would ... to the Land's-end" (2.30). The ease with which Sir Charles travels back and forth across the Channel is matched by a mental capacity that can entertain two religious sensibilities simultaneously. Clementina's brother notes, "It is hard, very hard ... for man, convinced of the truth of his religion, to allow to another of a different persuasion,

was guaranteed by her reproductive services, her willingness to undertake the lowly task of nursing her own child." "Colonizing the Breast: Sexuality and Maternity in Eighteenth-Century England," Eighteenth-Century Life 16 n.s. 1 (February 1992): 204.

15 The law, passed on May 22 1753, lifted the tax burdens and special restrictions imposed on Jewish merchants and allowed for the naturalization of those merchants after three years of residence. The backlash against the Act was immediate and vociferous, and the law was repealed later that year. On this subject, we know that Richardson denounced the "foolish, the absurd Cry" against the Act, and that elsewhere in his writing he addressed England's history of intolerance toward Jews (Kimpel and Eaves, Samuel Richardson, pp. 549, 552). In an unpublished essay, Elizabeth Kraft has considered the novel's treatment of its Jewish character, Solomon Merceda, noting that in the argument that sees Bagenhall pushing for Merceda's conversion, "Merceda is allowed the last word and given the upper hand." Paper presented at the ASECS annual meeting, Atlanta, GA, 2008. 
what he expects should be allowed for himself. You, Chevalier, however, can allow it: and have greatness of mind to judge favorably of those who cannot" (2. 582). Sir Charles links his tolerance to the expansiveness of Protestantism, writing to Clementina that "the Church of God, we hold, will be collected from the sincerely pious of all communions" (2.616). He repeats this refrain to Father Marescotti: "We Protestants confine not salvation within the pale of our own church" (2. 532). He describes his Protestantism as a personal preference - "the religion of my choice" (2.155) - and religious experience, more generally, as a private matter: "I would as soon quarrel with a man for his Face, as for his Religion" (3.141). But he also requires that his religious sensibility assume a public dimension: "good manners will make me shew respect to the religion of the country I happen to be in" (2.155). Following Locke, Grandison hopes that differences of private opinion may be subsumed under a higher law - that of politeness, among nations, and of the civil magistrate at home.

In her comparison of Clarissa's and Grandison's very different religious sensibilities, Margaret Doody notes that "in Grandison, Christianity ... is objective law, manifested in the outer world of social life and moral behavior. ${ }^{\prime 16}$ I would suggest that it is not Christianity, in fact, that serves as the objective law, but the novel makes it appear that it does while rendering unto Caesar what is Caesar's - or, in this case, Sir Charles's. When, for instance, Sir Charles concedes Clementina's right to bring a Catholic priest to England, should she marry him, he does so on the condition that her confessor prove "a discreet man," obedient to the laws of his family and nation (2.195). He is even more concerned that the Catholic servants who would attend Clementina recognize his higher authority, superior to that of their priest and mistress: "I must not be subject to the dominion of servants, the most intolerable of all dominion" (2.531). His wife's Catholicism, in other words, will never assume any authority in England. Its privacy is further ensured by the provision that would require sons-that is, heirs to the Grandison estate - to be raised Protestants. These concessions, for Grandison, reflect common sense, against which he contrasts the zeal of the Porretta family: "Religion and Love, Dr. Bartlett, which heighten our relish for the things of both worlds, What pity is it, that they should ever run

16 Doody, A Natural Passion, p. 274. Thackeray noted, in his 1868 remarks on Richardson, that Grandison's religion "is, in fact, merely the application of the laws of good society to the loftiest sphere of human duty." The Cornhill Magazine, Vol. XVII (Jan.-June, 1868), p. 60. 
the human heart either into enthusiasm, or superstition, and thereby debase the mind they are both so well fitted to exalt!" (2.220). The problem with Sir Charles's religious stance, however, is that it threatens to reduce religion to a solipsistic personal preference or an empty formal principle that merely buttresses civil authority. Sir Charles's inability to feel passionately, about love and religion, I suggest, registers as a lack in the novel. ${ }^{17}$

The Italian narrative brings the connection into sharp focus. Confronted with the Porrettas' initial intransigence on the subject of a union between their daughter and a Protestant, Sir Charles writes, "I laboured, I studied, for a compromise. I must have been unjust to Clementina's merit, and to my own Character, had she not been dear to me" (2.130). The oddness here appears in the equation Sir Charles draws between the labours involved in reaching a compromise and the mental work required to love Clementina. Indeed, Sir Charles never appears an active agent in that love story except when he is trying to come up with a contract that might contain the dangerous feelings inspired by religious difference. Discussing his return to Italy later in the narrative, he can only write, "The result cannot be in my own power ... . I make not any conditions for myself - My reward will be in the consciousness of having discharged the obligations that I think myself under, as a man of honour'"' $(2.382,384)$. If as a civil authority - executor, landowner, broker - Sir Charles wields power absolutely, in the empire of love he proves curiously incapable of lifting a sceptre. Reflecting on his condition, Sir Charles describes himself as "a man divided ... not knowing what I can do, hardly sometimes what I ought to do" (2.383). "The two noblest-minded women in the world, when I went over to Italy ... held an almost equal interest in my heart," he later writes (3.11). A divided heart requires discretion to protect its separate loyalties, and Sir Charles maintains his distance from those around him in order to serve the higher principles of honour and justice. He later writes, "had I been my own master ... Miss Byron, in the first hour that I saw her, would have left me no other choice" (3.53). Even at this moment, Sir Charles registers a strange passivity: had he not been acted upon by principle, he would have been acted upon by Harriet's beauty. Until he

17 Critics routinely note the strange absence at the core of Sir Charles. "He is a kind of black hole," Tassie Gwilliam observes, "sucking up the energy of others, producing no light" Samuel Richardson's Fictions of Gender (Stanford: Stanford Univ. Press, 1993), p. 150. Eaves and Kimpel note, "Sir Charles cannot write because there is no Sir Charles," Samuel Richardson, p. 397. See also, Jones, "The Dialectic of Love in Sir Charles Grandison," p. 32 and Doody, A Natural Passion, p. 274. 
hurls himself into marriage, Sir Charles lives in a state of limbo, writing, in his final narrative to Jeronymo, about the weeks after his first return from Italy: "I thought it became me, in honour, in gratitude, to hold myself in suspense" (3.10). Sir Charles imagines his emotional core as an empty space where competing interests must be regulated and supervised by the magistracy of his reason.

In a world where both Clementina's and Harriet's zeal proves so active and compelling, Sir Charles's restraint raises doubts about the man's emotional fitness. Wherein lies the appeal of a heart labouring under a sense of obligation? And who would want to possess such a heart? ${ }^{18}$ Harriet indicts Sir Charles's attachment to prudence when she re-casts him as Adam faced with Eve's fall, writing to Charlotte Grandison, "[Y]our brother would have had gallantry enough to his fallen spouse, to have made him extremely regret her lapse; but ... he would have done his own duty ... and left it to the Almighty, if such had been his pleasure, to have annihilated his first Eve, and given him a second" (2.609). Insofar as Sir Charles's habit of mind requires self-division, it compromises the idea of one complete mind meeting another, in the mutual recognitions of affective or religious alterity. As in affairs of the heart, so too in religious affairs it appears that only a singular attachment produces a truly ethical subjectivity capable or seeing another person clearly. When Father Marescotti bids farewell to Sir Charles, it is the intensity of his Catholic conviction that guarantees the emotional integrity of the moment: "begging my excuse, he kneeled down at the door of my antechamber, and offered up, in a very fervent manner, a prayer for my conversion. He could not have given me, any other way, so high an opinion of him" (220). Clementina urges Sir Charles to assume a Catholic identity when contemplating her final refusal, if only to see her for who she truly is: "If you cannot be a Catholic always, be a Catholic when you advise [me]" (2. 612). When Grandison debates with Clementina, in the closing pages of the novel, her desire to enter a convent, he takes on a Catholic persona: "I argue not as a protestant, when

18 This question preoccupies Harriet when she first entertains the idea that Sir Charles might love her: "who, my dear, large as his heart is, can be contented with half a heart?" (2.135). "Perhaps," Eaves and Kimpel speculate, "sensible charitableness is not the kind of goodness which can be imaginatively realized, perhaps it did not lie in the level of the mind from which poetry comes, as the goodness of Clarissa (and the vice of Lovelace) did" (Samuel Richardson, p. 398). That Harriet's affective zealotry proves a narrative spur while Charles's "sensible charitableness" kills representation on the page speaks, I believe, to the tension the novel stages between love and (limited) toleration. 
I address myself to you ... [Y]ou see, madam, I address[] myself to you in the catholic stile" (3.431). The moments when Sir Charles undertakes these imaginative identifications momentarily fill the emotional void we sense at his core.

This mode of identification leads us away from Locke's conceptualization of toleration as a civil issue guided by the need for peaceful coexistence, toward the more expansive thinking on the subject engaged in by Pierre Bayle. For Bayle, the only guide to divine law is individual conscience: "I am verily persuaded, that Almighty God, before he ever spoke by an external voice to Adam, to make him sensible of his Duty, spoke to him inwardly in his Conscience, by giving him the vast and immense Idea of a Being sovereignly perfect, and printing on his Mind the eternal Laws of Just and Honest." ${ }^{19}$ This "natural Light" continues to guide us when our natural passions do not interfere - passions as likely to be excited by sectarian conflict as by any other appetite. While Locke advocates (limited) toleration for the stabilization of civil society, Bayle more radically reaches for a new understanding of morality and individual freedom, one that requires an acceptance of absolute difference. Imaginatively we must entertain the idea of a parity among all systems of belief, even the moral legitimacy of non-belief, and accept that what appears to us as false conviction has the same rights as an enlightened one: "the Rights of an erroneous Conscience attended with Sincerity, are exactly the same as those of an Orthodox Conscience." ${ }^{\prime 20}$ Tolerance here involves a more radical suspension of identity politics than the model that allows error to take shelter under the umbrella of truth, for there is no stable vantage point from which one might claim a closer proximity to truth other than the ground provided by moral conduct, which anyone - including atheists - might assume.

Richardson admitted to having engaged in cross-cultural identification when he wrote about his Catholic subjects: "[I was] as zealous a Catholic when I was to personate the Lady, and her Catholic Friends, as a Protestant, when I was the Gentleman." ${ }^{21}$ The appeal of ventriloquism, of course, was not new to Richardson. But in this novel, heart-

19 Bayle, A Philosophical Commentary [based on a 1708 translation, the only complete English translation], ed. John Kilcullen and Chandran Kukathas (Indianapolis: Liberty Fund, 2005), p. 70.

20 Bayle, A Philosophical Commentary, p. 233.

21 Letter to Alexis Claude Clairaut, 5 July 1753. Selected Letters, p. 238. Richardson goes on to express his hope that he has done credit to the Catholic clergy, noting that "a very eminent Clergyman told me ... that I should be thought by some, to be 
felt speech takes on a political aspect. To hear the voice of another is to recognize, at some level, her rights. But this mode of recognition gives way to Protestant hegemony. ${ }^{22}$ It does so because the idea of religious difference, staged through reflections on interfaith marriage, necessarily returns us to the issue of sexual equality. As Harriet understands love as an abstraction to which sexless minds aspire, so Clementina imagines religious sensibility to be above social law. She assumes that Sir Charles might as easily convert to her faith as she to his: "I really look upon you ... as my fourth brother: I should be glad that all my brothers were of one religion" (2.154), she tells him. In a conversation with her mother she asks, "Might I not have had as great a chance of converting him, as he could have had of perverting me?" (2.208). The novel encourages us to believe that, like everyone else, Clementina will inevitably fall under the sway of Sir Charles's benevolent magistracy and convert to Protestantism, should she marry him. ${ }^{23}$ Looking back, Sir Charles writes, "Circumstanced as we were, how could I express the tenderness for her which overflowed my heart? ... [O]ught I, in generosity, in justice to her family, to have attempted to unsettle her in her faith in which she, and all her family, were so well satisfied?" (2.213). But where Harriet's willingness to submerge her philanthropic ambitions in the production of Grandison children appears part of a woman's maturation process rather than a fall into the constraints of socialization, the idea of Clementina's conversion more forcefully registers the compromising of a higher ideal, from the emancipatory vision of two faiths co-existing to the circumscribed - and profoundly gendered conditions imposed in the marriage Grandison imagines, including its privatization of women's religious belief. That Clementina is driven to madness because she cannot entertain love and religious attachment

more of a Catholic than a Protestant, for that I had made as amiable a Confessor, as a Protestant Divine."

22 The author of Critical Remarks on Sir Charles Grandison, Clarissa, and Pamela observed the limits of the novel's religious imagination: "You represent him [Sir Charles] ... to be a man universally learned, and tell us, at the same time in capital letters, that SIR CH. GRAN is a CHRISTIAN; and that, too, in the stricted and most bigotted sense of the word; for he refuses the woman he loves, for a difference in religious principles. This, in my humble opinion, is likewise an inconsistency, for universal learning leads to scepticism ..." (20).

23 Clementina names this fear as the reason she must not marry Grandison, claiming that her sense of Grandison's steadiness of principle and "of the duties of a good wife, will too probably stagger me in my faith" (2.585). Clementina's relation to her faith and the marriage plot is the subject of a longer version of this essay. 
simultaneously reveals, on one level, the novel's anti-Catholic sentiment - in this case manifest in Sir Charles's criticism of the Catholic church's willingness to pervert the "natural" course of a good woman's life by celebrating religious vocation as an alternative to domesticity - and, on another level, the cost of marriage to a man like Sir Charles.

Peter Sabor claims that "Sir Charles ... passes as citizen of the world, but is at heart John Bull." ${ }^{\prime 24}$ I suggest that Sir Charles becomes John Bull at heart only when he marries an English wife. Having landed safely in a Protestant union, Sir Charles can reassure Harriet that "the union of minds between us [that is, himself and Clementina] from difference of Religion, could not have been so perfect, as yours and mine must be" (3. 152). At this point, the novel makes amends for its hero's emotional compromises and attempts to justify Sir Charles's double-love retroactively. Sir Charles revises history so as to emphasize Harriet's superior claim to his affections, mostly by setting his early love for Harriet against a backdrop of pity for Clementina: "Compassion for the one Lady, because of her calamity, might, at that time, I found, have been made to give way, could those calamities been overcome, to Love for the other" (3.54). We are encouraged to pair Clementina with Sir Charles' charitable mind and Harriet with his heart, so that it is less the good luck and good timing of Clementina's final refusal than the overarching love between Sir Charles and Harriet that motivates the marriage plot. In the present, Sir Charles compensates for the betrayal of his first love another way, by imagining that she lives in Harriet, to whom he observes: "You are Clementina and Harriet, both in one: One mind certainly informs you both" (3.191). But such a claim can only strike us as a palpable, and slightly grotesque, fiction. In a darker register, we know that if Sir Charles loved Harriet from the moment they met, he was capable of entering into a marriage with Clementina harbouring adulterous feelings. And if he didn't love Harriet spontaneously, but only upon deliberation, then she is, indeed, a second-class citizen in the country of love. Richardson can sustain the integrity of Sir Charles's character only by falling back on the idea of sexual difference. Lady G. notes that "the man who loves virtue for virtue's sake, loves it whereever he finds it: Such a man may distinguish more virtuous women than one" (2.352). ${ }^{25}$ By this account, men's access to a wider range of

24 Sabor, "'A Safe Bridge Over Narrow Seas': Crossing the Channel with Samuel Richardson," 1660-1780: All Before Them, ed. John McVeagh (London: Ashfield Press, 1990), p. 168. 
individuals and experiences means they might meet more than one angel of virtue in their courtship years and thus find themselves drawn, circumstantially, into the dilemma faced by Sir Charles. Richardson framed the topic more abstractly in a letter to Lady Bradshaigh: "The Apostle says, Woman was made for Man, not Man for Woman. It would be the greatest of Indelicacies for a Woman to be thought to love two Men at the same time equally," before going on to joke that a bigamous marriage might resolve the question most successfully. ${ }^{26}$

In their criticism of Sir Charles Grandison, Eaves and Kimpel argue that "Richardson did not understand that if an author is to convey a quality, a feeling, a value, he must infect the reader." ${ }^{27}$ But Clarissa's success demonstrates that Richardson understood this idea very well indeed. In that novel, infection, both among characters and between the novel and its readers, was "cured" by the death of the novel's principles - we never have to imagine how Clarissa's ethical system might find expression as a social program, nor what authority might prove itself capable of controlling Lovelace's libertinism. In Grandison, Richardson faced the larger problem of reconciling the religious and affective attachments of both his characters and his readers to the social imperatives he valued most. The novel's endorsement of the language of the heart speaks to its desire to rebuke the hypocrisies of both libertines and xenophobic clerics. But its engagement with the subjects of love and toleration threatens to upset the careful balance the novel strikes between its sympathy for women and religious minorities and its commitment to the social magistracy - and unquestioned authority - of its Good Man. In the final instance, Richardson could not entertain a political solution to the inequalities of religious and sexual difference without undermining his commitment to the cultural authority of paternalist governance.

His response to the anti-Semitic backlash against the Jewish Naturalization Act is revealing in this instance. In a letter to Elizabeth Carter, Richardson suggests that individuals in favor of the Act might be better off letting political sleeping dogs lie. Jews ought to go along with the movement to repeal the Act, he writes, since it serves no practical end for English-born subjects, only inciting hatred against them in a coun-

says, Woman was made for Man, not Man for Woman. It would be the greatest of Indelicacies for a Woman to be thought to love two Men at the same time equally." Selected Letters, p. 253.

8 Dec. 1753, Selected Letters, p. 252. 
try "which they honour for the Liberty of Conscience and the Safety of Property given them in it." ${ }^{28}$ This logic echoes that of the novel. On the one hand, England stands, abstractly, for the principles of liberty of conscience and safety of property; on the other hand, those principles are only protected when individuals maintain their belief in them privately rather than agitating for their security in the public sphere. What we don't encounter is the means by which private conviction of equality might find security in the law. In the novel, sexual difference minds the gap. Harriet embodies private conviction, which Grandison secures as landowner and citizen, and together we imagine they will preside over their estate harmoniously and set an example to the larger public. Harriet's private zeal is worthy because she is a woman and proper love is her proper subject; Sir Charles's cosmopolitanism allows his estate, writ large as the nation, to imagine itself a partner among equals in Europe. Charlotte's description of the happy couple's performance of the wedding service sums up the difference neatly: "Sir Charles seemed to have the office by heart; Harriet in her heart" (3.226). Only Clementina cannot fit into this equation.

Interfaith marriage complicates Richardson's division of labor by bringing into view the public aspect of women's religious conviction, its ability to command loyalty as a higher law at the expense of the domestic. Reviewing Richardson's correspondence recently, it did not surprise me to discover that it was a woman's religious activism that inspired the author to pick up the pen to write his first ventriloquized letter, nor that he was reflecting on this first letter the year he was completing the first six volumes of Grandison:

I was not Eleven Years old, when I wrote, spontaneously, a Letter to a Widow of near Fifty, who, pretending to a Zeal for Religion, \& who was a constant Frequenter of Church Ordinances, was continually fomenting Quarrels \& Disturbances, by Backbiting \& Scandal, among all her Acquaintance. I collected from ye Scripture Texts that made against her Assuming the Stile and Address of a Person in Years, I exhorted her; I expostulated with her. But my Handwriting was known. ${ }^{29}$

Religious difference here expresses itself, not in the lament of a young Catholic woman, but in the voice of an evangelical "widow of near fifty," whose zeal the young Richardson corrects by mustering all the 
rhetorical and scriptural authority gleaned in his eleven years. Richardson's fear of women's claims to religious authority appears again in his description of an early marriage proposal: "A pretty ideot was once proposed ... A violent Roman Catholic lady was another, of a fine fortune, a zealous professor, whose terms were (all her fortune in her own power - a very apron-string tenure!) Two years probation, and her confessor's report in favour of his being a true proselyte at the end of them. ${ }^{\prime 30}$ Here the scandal is deepened by the Roman Catholic lady's attachment to both her fortune and a man other than her intended, namely, her confessor. Clementina's threat contains itself, almost, in the immaturity of her character and in the pathos Richardson evokes when narrating her story. And yet in novel's anxiety about the possibility of servant insubordination and the presence of Catholic priests in England we glimpse the larger problem posed by a woman whose faith challenges her spouse's prerogative.

The controversy generated by Grandison's engagement with the issues raised by the Jewish Naturalization and Hardwicke Marriage Acts of 1753 reflect the stakes governing both marriage and toleration in eighteenth-century Britain. ${ }^{31}$ In the end, Richardson could go no further with the radical ideas his novel introduces than to engage our sympathy with their advocates, even as he argues for their necessary subjugation to the higher law maintained by his Good Man. Despite their limitations, Grandison's meditations on equality between the sexes and religious toleration cast light on the novel's historical development after 1750. If critical narratives tend to stress the novel's move away from religious controversy in the latter half of the eighteenth century, the issue of interfaith marriage reminds us of the xenophobia and unrest that culminated in the Gordon Riots of 1780. Literature contributed to religious controversies at crucial moments, as when Shakespeare's Merchant of Venice was invoked in the backlash against the Jewish Naturalization Act. ${ }^{32}$ The idea that the marriage plot could resolve or alleviate political tensions by offering a compelling model of sociability is tested by the idea of an interfaith union, whose competing loyalties both lay

30 To Lady [1755]; Selected Letters, p. 323.

31 Eve Bannet notes the gap introduced by the Hardwicke Marriage Act between the moral foundation of marriage, which allowed a vow to constitute a bond "in conscience," and the new legal imperatives imposed on women seeking protection of their union under the law.

32 James Shapiro, Shakespeare and the Jews (New York: Columbia Univ. Press, 1996), p. 78 . 
bare and contest the asymmetry of power in the gender relations that structured marriage throughout the century. ${ }^{33}$ At the same time, those women who, like Harriet and Clementina, claim the equality of minds and belief systems reveal the limits governing the conventions of toleration that had emerged in Locke's wake, opening up that conversation to a broader consideration of the grounds upon which a deeper, more reciprocal tolerance might appear. ${ }^{34}$

\section{ALISON CONWAY}

University of Western Ontario

33 For a powerful analysis of the eighteenth-century novel's engagement with this asymmetry, see Helen Thompson, Ingenuous Subjection: Compliance and Power in the Eighteenth-Century Domestic Novel (Philadelphia: Univ. of Pennsylvania Press, 2005). Of Sir Charles Grandison, Betty Schellenberg observes, "It is on one level a celebration of 'femality,' allowing extensive play to the desires, imaginations, and private concerns of women, and on another a rigid subjection of that femality to the gender hierarchy of the day." "Using 'femalities' to 'make fine men': Richardson's Sir Charles Grandison and the feminization of narrative." Studies in English Literature, 1500-1900 34.3 (1994): 613.

34 My thanks to Elizabeth Kraft and Betty Schellenberg for their comments on this essay. 